\title{
IMPLEMENTASI MODEL PEMBELAJARAN GUIDED DISCOVERY UNTUK MENINGKATKAN AKTIVITAS DAN HASIL BELAJAR PESERTA DIDIK SMA NEGERI 2 PEKANBARU
}

(Implementation of Guided Discovery Learning Model to Improve Activities and Learning Outcomes of Students in SMA Negeri 2 Pekanbaru)

\author{
$\operatorname{Kasim} *)$ \\ e-mail : kasimkasim@gmail.com
}

*) Guru SMA Negeri 2 Pekanbaru, Riau

\begin{abstract}
This study aims to improve the activities and learning outcomes of students in PPKn lessons, especially in the subject matter of state institutions according to the 1945 Constitution of the Republic of Indonesia through guided discovery learning models using student worksheet media (LKPD) towards students of class X MIPA 1 SMAN 2 Pekanbaru. This research is a Classroom Action Research (CAR) which takes place in 2 (two) cycles. Each cycle consists of four stages, namely planning, acting, observing and reflecting. The results showed that the application of guided discovery learning models can increase student learning activities with the results of the average activity value of the first cycle was 72.6 and the average cycle II was 82.9. This indicates that in general students are classified as active in learning. The application of guided discovery learning models also improves the cognitive abilities of students with the learning outcomes obtained in cycle I (mean $=79.72)$ and cycle II (average $=83.06)$.
\end{abstract}

Keywords: Classroom action research, guided discovery, learning activities and outcomes.

\section{PENDAHULUAN}

Kualitas kehidupan bangsa salah satunya ditentukan oleh faktor pendidikan. Kualitas pendidikan yang rendah akan berakibat pada rendahnya kualitas kehidupan bangsa. Peningkatan dan perbaikan mutu pendidikan tidak dapat terlepas dari berbagai upaya. Komponen yang harus diperhatikan sebagai upaya untuk menciptakan mutu pendidikan yang lebih baik yaitu guru selaku pendidik, siswa selaku siswa, serta cara atau metode yang dipakai untuk mencapai suatu tujuan pendidikan yang telah tertuang didalam rencana pelaksanaan pembelajaran. Kegiatan belajar merupakan kegiatan yang paling pokok dalam keseluruhan proses pendidikan disekolah (Slameto, 2010).

Berdasarkan observasi dan kajian data pada pembelajaran pada materi
PPKN, diketahui bahwa masih banyak peserta didik mengalami kesulitan dalam memahami materi PPKN, salah satunya yaitu materi pokok Ketentuan UUD NRI tahun 1945 yang mengatur wilayah negara, warga negara dan penduduk, agama dan kepercayaan, pertahanan dan keamanan. Persentase ketercapaian peserta didik yang mencapai KKM (78) pada penilaian harian sebesar $61 \%$ dengan nilai rata-rata 76,00. Sebanyak 14 orang peserta didik memperoleh nilai di atas rata-rata dan 15 orang peserta didik memperoleh nilai di bawah rata-rata. Kurang kuatnya konsep peserta didik inilah yang diindikasikan sebagai penyebab lemahnya pemahaman peserta didik terhadap materi pembelajaran.

Berdasarkan observasi peneliti di kelas, terdapat beberapa permasalahan yang terjadi dan dihadapi dalam kegiatan 
belajar antara lain adalah: 1) Kurangnya pemahaman konsep materi belajar oleh peserta didik menyebabkan pada penyajian materi masih sering dilakukan dengan metode ceramah dan diskusi sehingga menjadikan guru sebagai pusat belajar (teacher centered), 2) Keterlibatan peserta didik yang masih rendah dalam kegiatan belajar, dimana peserta didik terbiasa hanya mencatat dan mendengarkan guru, 3) Kurang memadainya sarana dan prasarana yang ada untuk melakukan kegiatan praktikum, 4) Kurangnya referensi dan sumber belajar yang baik bagi peserta didik, 5) Kurangnya motivasi peserta didik dalam kegiatan belajar karena kegiatan yang berlangsung terkesan monoton.

Berdasarkan permasalahan tersebut, maka diperlukan tindakan untuk memperbaiki kualitas dari proses dan produk belajar peserta didik agar menjadi lebih baik. Salah satu cara untuk memperbaiki kualitas proses dan hasil belajar tersebut yaitu dengan penerapan suatu model pembelajaran yang sesuai dengan karakteristik materi dan kondisi peserta didik (Trianto, 2011). Metode pembelajaran ilmiah memiliki beberapa model yang disesuaikan dengan tingkat kesulitan dan karakteristik materi serta kondisi peserta didik, sehingga pembelajaran ilmiah dapat diterapkan dengan model pembelajaran berlandaskan paradigm konstruktivisme. Salah satu model pembelajaran ilmiah berlandaskan teori konstruktivisme yang dapat diterapkan dalam kegiatan pembelajaran adalah Model pembelajaran penemuan terbimbing (Guided Discovery).

Sehubungan dengan pemikiran di atas, maka dilakukan penelitian untuk meningkatkan aktivitas dan hasil belajar peserta didik kelas X MIPA 1 pada materi pokok Kewenangan Lembaga Lembaga Negara Menurut UUD RI Tahun 1945 menggunakan model pembelajaran guided discovery di kelas
X MIPA 1 SMAN 2 Pekanbaru.

\section{Aktivitas Belajar}

Aktivitas adalah kegiatan yang bersifat fisik maupun mental, yaitu berbuat dan berfikir sebagai suatu rangkaian yang tidak dapat dipisahkan (Sardiman, 2001). Aktivitas belajar peserta didik saat ini dipengaruhi berbagai faktor, diantaranya adalah: (1) memberikan motivasi atau menarik perhatian peserta didik, sehingga mereka berperan aktif dalam kegiatan pembelajaran; (2) menjelaskan tujuan instruksional (kemampuan dasar kepada peserta didik); (3) mengingatkan kompetensi belajar kepada peserta didik; (4) memberikan stimulus (masalah, topik, dan konsep yang akan dipelajari); (5) memberikan petunjuk kepada peserta didik cara mempelajari; (6) memunculkan aktivitas, partisipasi peserta didik dalam kegiatan pembelajaran, (7) memberikan umpan balik (feedback); (8) melakukan tagihantagihan kepada peserta didik berupa tes sehingga kemampuan peserta didik selalu terpantau dan terukur; (9) menyimpulkan setiap materi yang disampaikan diakhir pembelajaran (Iriani, 2012).

Kegiatan belajar mengajar bagi peserta didik diorientasikan pada keterlibatan intelektual, emosional, fisik dan mental maka aktivitas belajar peserta didik digolongkan sebagai berikut:

1) Visual activities, seperti membaca, memperhatikan gambar, demonstrasi, percobaan dan sebagainya.

2) Oral activities, seperti menyatakan, merumuskan, bertanya, memberi saran, mengeluarkan pendapat, mengadakan interview, diskusi, interupsi dan sebagainya.

3) Listening activities, seperti mendengarkan uraian, percakapan, diskusi, musik, pidato, dan sebagainya. 
4) Writing activities, seperti menulis cerita, karangan, laporan, tes, angket, menyalin, dan sebagainya.

5) Drawing activities, seperti menggambar, membuat grafik, peta, diagram, pola, dan sebagainya.

6) Motor activities, seperti melakukan percobaan, membuat konstruksi, model, mereparasi, bermain, berkebun, memelihara binatang, dan sebagainya.

7) Mental activities, seperti menanggap, mengingat, memecahkan soal, menganalisis, melihat hubungan, mengambil keputusan, dan sebagainya.

8) Emosional activities, seperti menaruh minat, merasa bosan, gembira, berani, tenang, gugup, dan sebagainya (Sardiman, 2000).

\section{Hasil Belajar}

Setiap kegiatan belajar akan berakhir dengan hasil belajar. Hasil belajar tiap peserta didik di kelas terkumpul dalam himpunan hasil belajar kelas. Bahan mentah hasil belajar terwujud dalam lembar - lembar jawaban soal ulangan atau ujian, dan yang berwujud karya atau benda. Menurut Dimyati dan Mudjiono (2009), Semua hasil belajar tersebut merupakan bahan yang berharga bagi guru dan peserta didik. Bagi guru, hasil belajar peserta didik di kelasnya berguna untuk melakukan perbaikan tindak mengajar dan evaluasi. Bagi peserta didik, hasil belajar tersebut berguna untuk memerbaiki cara-cara belajar lebih lanjut. Oleh karena itu, pada umumnya guru mengadakan analisis tentang hasil belajar peserta didik di kelasnya.

Rumusan tujuan pendidikan dalam sistem pendidikan nasional, baik tujuan kurikuler maupun tujuan instruksional, menggunakan klasifikasi hasil belajar dari Benyamin Bloom dalam Sardiman (2009) yang secara garis besar membaginya menjadi tiga ranah, yakni kognitif, afektif, psikomotor.

\section{Model Pembelajaran Guided Discovery}

Model pembelajaran penemuan terbimbing (Guided Discovery) merupakan pendekatan mengajar yang berusaha meletakkan dasar dan mengembangkan cara berfikir ilmiah. Model ini menempatkan peserta didik lebih banyak belajar sendiri, mengembangkan kekreatifan dalam memecahkan masalah. Peserta didik betul-betul ditempatkan sebagai subyek yang belajar. Peranan guru dalam pendekatan penemuan terbimbing (Guided Discovery) ini adalah pembimbing belajar dan fasilitator belajar.Tugas utama guru adalah memilih masalah yang dilontarkan kepada kelas untuk dipecahkan oleh peserta didik sendiri (Sagala, S. 2007).

Pembelajaran dengan menggunakan model guided discovery bertujuan untuk memperbaiki pola pengajaran yang selama ini hanya mengarah kepada menghafal fakta-fakta saja, tetapi tidak memberikan kepada peserta didik pengertian konsep- konsep dan atau prinsip-prinsip yang terdapat dalam suatu materi pelajaran. Pada pembelajaran guided discovery ini peserta didik melakukan percobaan dengan mengamati fenomena - fenomena yang berhubungan dengan materi yang terjadi disekitar mereka serta mengumpulkan informasi dari hasil pengatan tersebut untuk menjawab pertanyaan-pertanyaan yang diberikan guru dalam upaya menemukan konsep-konsep berdasarkan data yang diperoleh dan membandingkannya dengan teori yang terdapat dalam modul atau buku pelajaran. Dengan demikian, peserta didik diharapkan dapat mengembangkan ketrampilan berfikirnya dengan menemukan sendiri konsepkonsep dari materi yang diajarkan dan pemahaman konsep peserta didik akan lebih bersifat permanent atau tidak akan mudah hilang dari ingatan. Berdasarkan pendapat tersebut maka dapat 
disimpulkan model pembelajaran penemuan terbimbing (guided discovery learning) merupakan model pembelajaranyang melibatkan peserta didik belajar secara aktif dan mandiri dalam pembelajaran.

Menurut Syah (2014), terdapat beberapa prosedur yang harus dilaksanakan dalam kegiatan belajar penemuan, yaitu; (1) stimullus (pemberian perangsang / stimuli), (2) problem statement (mengidentifikasi masalah), (3) data collection (pengumpulan data), (4) data processing (pengolahan data), (5) verification, dan (6) generalisasion.

\section{METODOLOGI PENELITIAN}

Penelitian yang dilakukan ini menggunakan rancangan penelitian tindakan kelas atau classroom action research).

Subjek dalam penelitian ini adalah peserta didik kelas X MIPA 1 SMA Negeri 2 Pekanbaru pada semester ganjil tahun pelajaran 2017/2018 yang berjumlah 36 orang. Pemilihan kelas $\mathrm{X}$ MIPA 1 sebagai subjek penelitian dilakukan atas pertimbangan bahwa mata pelajaran PPKN khususnya materi Kewenangan Lembaga- Lembaga Negara Menurut UUD Negara Republik Indonesia Tahun 1945 dipelajari di kelas $\mathrm{X}$ ini berdasarkan sebaran KI-KD sesuai kurikulum 2013.

Penelitian tindakan kelas dilaksanakan ini terdiri dari dua siklus dimana pada setiap siklusnya terdiri dari dua kali pertemuan dan pada tiap siklusnya meliputi empat tahap yaitu perencanaan, pelaksanaan, observasi, dan refleksi. Berbagai tahap dan kegiatan pada siklus kedua pada dasarnya sama dengan siklus pertama, hanya saja tindakan yang dilakukan berbeda. Tindakan pada siklus kedua ini berdasarkan hasil refleksi pelaksanaan siklus pertama.

Penelitian ini menggunakan metode deskriptif dengan membandingkan hasil belajar dan aktivitas peserta didik pada siklus I dan siklus II.

\section{HASIL PENELITIAN}

Penilaian hasil belajar peserta didik secara kognitif diperoleh dari skor mengerjakan tes yang diujikan pada setiap siklus diakhir pembelajaran dapat diamati pada Gambar 1. Sedangkan perbandingan nilai aktivitas belajar peserta didik tiap siklus peserta didik dapat dilihat pada

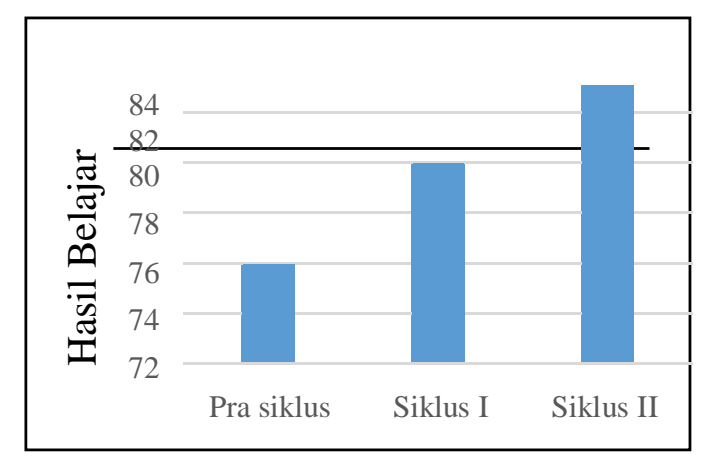

Gambar 1. Grafik nilai rata-rata hasil belajar tiap siklus.

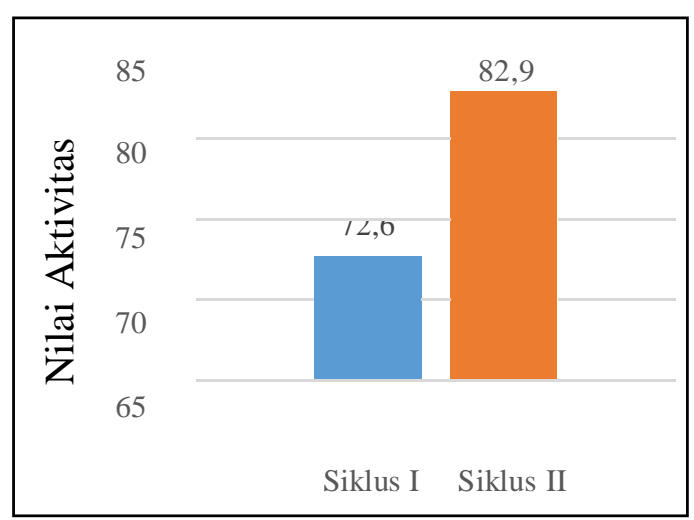

Gambar 2. Grafik nilai rata-rata aktivitas belajar tiap siklus.

\section{PEMBAHASAN}

Hasil observasi, wawancara, dan hasil belajar terhadap peserta didik pada materi pokok kompetensi dasar sebelumnya yaitu materi nilai-nilai pancasila dalam kerangka praktik penyelenggaraan pemerintah negara menunjukkan bahwa penerapan metode belajar ceramah dan tanya jawab kurang meningkatkan aktivitas dan kompetensi 
peserta didik sehingga model pembelajaran tersebut diganti dengan model pembelajaran yang sesuai dengan karakterisitik, daya serap dan kondisi peserta didik yaitu model pembelajaran guided discovery dengan menggunakan metode diskusi dan tanya jawab yang dilengkapi dengan LKPD. Penggunaan media LKPD bertujuan agar materi PPKn yang semula bersifat abstrak menjadi konkret sehingga peserta didik memperoleh pemahaman materi yang lebih yang pada akhirnya dapat meningkatkan aktivitas dan hasil belajar peserta didik.

Hasil observasi siklus I menunjukkan bahwa peserta didik masih merasa asing dengan model pembelajaran guided discovery learning. Hal ini tampak pada pertemuan pertama, Semua peserta didik aktif mencatat, tetapi hanya beberapa peserta didik yang aktif menjawab pertanyaan, peserta didik masih ada yang belum memahami sepenuhnya materi suprastruktur politik dan infrastruktur politik, namun sebagian besar tampak lebih antusias dan termotivasi dalam mencari informasi terkait materi ajar. Suasana belajar lebih bersemangat pada pertemuan kedua ketika memasuki materi Lembagalembaga Negara Republik Indonesia Menurut UUD NRI tahun 1945. Peserta didik antusias dalam diskusi mengenai lembaga-lembaga dalam sistem ketatanegaraan Indonesia. Hanya beberapa peserta didik yang kesulitan memahami materi karena merasa bosan, kurang konsentrasi dan merasa materi yang disampaikan sulit dimengerti. Berdasarkan hasil observasi sikap peserta didik terhadap pembelajaran, pembelajaran menggunakan model pembelajaran guided discovery pada siklus I secara umum menarik karena guru memberikan penjelasan, peserta didik umumnya aktif menggali informasi mengenai materi melalui kajian literatur dan bahan ajar yang diberikan.

Selain itu tampak adanya sikap kerjasama dan tanggungjawab antara peserta didik melalui tugas kelompok. Secara umum peserta didik memahami penyampaian informasi bahan ajar sebab materi yang disampaikan menarik dan tidak sulit. Namun saat guru menunjuk peserta didik untuk mengajukan pertanyaan, ternyata masih ada yang belum memahami konsep materi yang disampaikan, peserta didik merasa jenuh dan kurang konsentrasi. Hal ini dikarenakan pembelajaran masih didominasi pada guru sehingga peserta didik kurang aktif. Hasil tes kognitif menunjukkan bahwa hanya 16 orang peserta didik yang memperoleh nilai $\geq$ 80 dengan nilai rata-rata kelas 79,72 dan persentase ketuntasan sebesar $69,44 \%$. Hasil observasi aktivitas belajar peserta didik dengan nilai rata 72,6 mengindikasikan bahwa peserta didik dikatakan aktif dalam proses pembelajaran.

Sebagai refleksi terhadap siklus I maka guru tetap menggunakan model pembelajaran discovery learning pada siklus II menggunakan LKPD disertai tugas proyek yang dikerjakan diluar jam pelajaran. Tugas proyek dilakukan secara berkelompok lalu dipresentasikan di kelas dan dinilai dalam bentuk unjuk kerja presentasi. Dasar pemilihan media ini disesuaikan dengan materi ajar sehingga diharapkan dapat membantu peserta didik memperoleh pemahaman mendalam terhadap materi yang disampaikan. Hasil observasi peserta didik pada siklus II menunjukkan adanya peningkatan aktivitas belajar peserta didik. Guru memberikan bimbingan pada masing-masing kelompok untuk pengerjaan LKPD diskusi sebagai upaya agar pengerjaan LKPD terarah dan tidak menimbulkan miskonsep. Selama pembelajaran, guru dan observer mengamati aktivitas peserta didik. Peserta didik sudah terbiasa dengan model pembelajaran guided discovery, suasana belajar lebih kondusif, diskusi berjalan lancar, dan pembelajaran selesai 
tepat waktu..

Hasil tes kognitif siklus II menunjukkan peningkatan dibandingkan daripada siklus sebelumnya. Sebanyak 35 orang peserta didik memperoleh nilai $\geq$ 80 , dengan nilai rata-rata kelas sebesar 83,06 dan persentase ketuntasan 97,22\%. pada siklus II adalah 85,02. Hasil observasi aktivitas belajar peserta didik pada siklus II dengan nilai rata 82,9 mengindikasikan bahwa peserta didik dikatakan aktif. Peningkatan aktivitas dan hasil belajar dikarenakan peserta didik sudah mulai terbiasa menggunakan media LKPD sehingga aktivitas belajar meningkat, guru tetap memberikan bimbingan intensif pada masing-masing kelompok dalam mengerjakan LKPD. Kelompok yang menjawab LKPD dengan benar akan mendapatkan poin lebih sehingga peserta didik semakin aktif dan menyadari pentingnya kerjasama dalam kelompok untuk memberikan nilai terbaik.

Peningkatan aktivitas dan ketercapaian kompetensi hasil belajar peserta didik tidak terlepas dari keberhasilan guru dalam menerapkan model, metode dan media pembelajaran, yang didukung dengan adanya perbaikan proses pembelajaran lebih baik pada tiap siklus.

\section{SIMPULAN}

Berdasarkan hasil penelitian dan pembahasan dapat disimpulkan bahwa :

1. Penerapan model pembelajaran guided discovery meningkatkan aktivitas peserta didik dengan nilai aktivitas rata- rata siklus I adalah 72,6 dan meningkat pada siklus II dengan nilai aktivitas 82,9 mengindikasikan secara umum peserta didik tergolong aktif dalam pembelajaran

2. Penerapan model pembelajaran guided discovery dapat meningkatkan kemampuan kognitif peserta didik dengan hasil yang diperoleh yaitu pada siklus I (rata-rata $=79,72$ ) dan siklus II (rata-rata $=83,06)$.

\section{REFERENSI}

Dimyati \& Mudjiono. 2006. Belajar dan Pembelajaran. Jakarta: Rineka Cipta Sardiman, 2010, Interaksi dan Motivasi Belajar Mengajar, Raja Grafindo Persada, Jakarta

Istiqomah. 2014. Penerapan Model Guided Discovery Learning Untuk Meningkatkan Motivasi dan Hasil Belajar Siswa Kelas IVB SD Negeri 02 Tulung Balak Kabupaten Lampung Timur. Skripsi, Lampung: Universitas Lampung.

Khabibah, Rani. 2014. Pengaruh Model Guided Discovery Learning Terhadap Hasil Belajar Siswa SMA Pada Konsep Gerak Melingkar Beraturan. Skripsi, Jakarta: UIN Syarif Hidayatullah.

Melani, R. 2012. Pengaruh Metode Guided Discovery learning Terhadap Sikap Ilmiah dan Hasil Belajar Kognitif Biologi Siswa SMA Negeri 7 Surakarta Tahun Pelajaran 2011/2012. Pendidikan Biologi FKIP UNS. 4 (1) : 97-105

Slameto. 2010. Belajar dan FaktorFaktor yang Mempengaruhinya.. Rineka Cipta, Jakarta

Trianto. 2007. Model-Model Pembelajaran Inovatif Progresif Berorientasi Konstruktivistik Prestasi Pustaka, Jakarta 